\title{
REPRESENTATIONS OF VIOLENCE IN SOCIAL SCIENCE TEXTBOOKS: RETHINKING OPPORTUNITIES FOR PEACEBUILDING IN THE COLOMBIAN AND SOUTH AFRICAN POST-CONFLICT SCENARIOS
}

Diana Rodríguez-Gómez

Universidad de Los Andes

Email: dm.rodriguez@uniandes.edu.co

Kim Foulds

University Research Co.

Email: kimfoulds@gmail.com

\section{Yusuf Sayed}

University of Sussex

Email:Y.Sayed@sussex.ac.uk

Centre for International Teacher Education (CITE)

Email: sayedy@cput.ac.za

\section{ABSTRACT}

Recent years have witnessed violence in educational settings becoming an object of public concern and global mobilisation. International initiatives indicate rising levels of awareness regarding the interconnectedness of violence and education. In this context, international educational agendas identify violence in schools as a challenge to the fundamental rights of children, and as a hindrance to social and economic development. Yet, most of these global initiatives focus on acts of

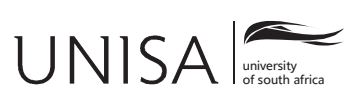

Education as Change

Volume 20 | Number 3 | 2016 | pp. 76-97

www.educationaschange.co.za
DOI: http://dx.doi.org/10.17159/1947-9417/2016/1532 Print ISSN 1682-3206 | Online 1947-9417

(C) 2016 The Author(s) 
violence - more specifically on teachers' and students' behaviours - neglecting the role of curriculum and textbooks as potential peacebuilding devices. In this study, we analyse the role of textbooks as peacebuilding tools in Colombia and South Africa. These two countries, while situated at different sites on the conflict/post-conflict continuum, both continue to confront the inextricable impact of conflict on social cohesion and peacebuilding. Through an analysis of how Grade 9 social studies textbooks in these countries explain past conflict and how those representations articulate national conflict as part of the peacebuilding process, we find that while there is an extended presence of topics related to conflict and peacebuilding, the textbooks inadequately explore the structural dimension of violence, and the interconnectedness between individual actions, and broader societal arrangements. Rather, through incomplete historical narratives of physical violence, we find that the textbooks analysed become intermediaries of structurally violent regimes, reinforcing the processes and systems that maintain such arrangements.

Keywords: textbooks; violence; peacebuilding

\section{INTRODUCTION}

Recent years have witnessed violence in educational settings becoming an object of public concern and global mobilisation. Initiatives such as the International Network for Education in Emergencies (INEE) and the United Nations International Decade for a Culture of Peace and Non-Violence (2001-2010) have been supported by reports such as the United Nations' study Violence against Children (2006), the United Nations Educational, Scientific, and Cultural Organization's (UNESCO) (2011) Global Monitoring Report entitled The Hidden Crisis: Armed Conflict and Education, and the United Nations International Children's Emergency Fund's (UNICEF) (2012) Tackling Violence in Schools: A Global Perspective. Additionally, programmes and campaigns such as UNICEF's Learning for Peace (2012-2015) and Plan International's Learn without Fear (2008-present) indicate rising levels of awareness regarding the interconnectedness of violence and education. In this context, international educational agendas identify violence in schools as a challenge to the fundamental rights of children, and as a hindrance to social and economic development. Yet, most of these global initiatives focus on acts of violence - more specifically on teachers' and students' behaviours - neglecting the role of curriculum and textbooks as potential peacebuilding devices.

As the most public and accessible aspect of the written curriculum, textbooks have the capacity to address past and present injustices, promote the recognition of difference, and create opportunities for equitable participation in the classroom. Furthermore, textbooks offer great prospects to understand how societies that endure high levels of violence strategise repertoires of peacebuilding to promote social change. This reality is particularly true for those countries emerging from a history of conflict 
and division, as are the cases of Bosnia and Herzegovina, Guatemala, Rwanda, South Africa, and South Sudan (Bellino 2014; Brown 2011; Engelbrecht 2008; Freedman et al. 2008; Low-Beer 2001). In states emerging from conflict, governments have looked toward revised national curricula to provide new directions in national narratives and promote a new national identity. While this is the trend, INEE, a leader in the provision of education in conflict-affected regions, advocates for curriculum revisions even in the midst of conflict. Regardless of when revisions take place, we argue that content that promotes peacebuilding demands a critical analysis of the connections between the multiple causes of violence, and direct and indirect individual actions (Farmer 2004). To turn textbooks into a foundation for non-violent narratives, and into opportunities for conflict management and resolution, content revision must create spaces for students to connect broader societal issues with their own place in society.

To understand the challenges associated with the representation of violence in the conflict/post-conflict continuum, we focus on Colombia and South Africa because, while situated at different places on this continuum, both states continue to confront the inextricable impact of conflict on social inclusion and cohesion.

After 60 years of armed conflict, Colombia is currently holding a peace plebiscite with the Revolutionary Armed Forces of Colombia (FARC) - the oldest left-wing guerrilla in Latin America. In a recent study that included 28,967 students from public schools, 22.5 per cent of the total sample reported practising some type of violence in school, and 56.8 per cent self-identified as a victim of bullying (Plan Internacional 2014). Under the Colombian General Education Law, schools are highly decentralised. This means schools design their own curricula and make decisions over the pedagogical materials they want to use in the classroom (Chaux 2009). Due to the recent agreement on a bilateral ceasefire, and the prospects of a final peace accord between the government and the FARC, peace-education initiatives that involve the design and implementation of new learning materials are mushrooming.

In South Africa, the end of apartheid in 1994 and the establishment of the Truth and Reconciliation Commission in 1996 initiated a contentious peace at best. In 2011, South Africa unveiled revised Curriculum and Assessment Policy Statements (CAPS), which were focused on healing divisions of the past. Evidencing high levels of public awareness regarding the persistence of violence, in 2012, in collaboration with the Open Society Foundation and UNICEF, the Centre for Justice and Crime Prevention published the second National School Violence Study (Burton \& Leoschut 2013). The document reports that, from a total of 5,939 interviewees, more than one-fifth had experienced violence at school, as a victim, a victimiser, or a witness.

This article examines violence and peacebuilding narratives in social studies secondary textbooks in both Colombian and South African contexts, and we analyse the possibilities these textbooks offer for peacebuilding. More specifically, we address how textbooks represent violence, and explore the opportunities these representations entail for the construction of peace. Through a comparative lens that pays attention 
to written and visual content as well as instructional issues, we tackle the following questions: How do textbooks explain past and present injustices? How do textbooks manage the challenges of (re)presenting armed conflict within the challenges of high levels of violence? Drawing on a definition of peacebuilding that incorporates debates about structural violence, this paper finds that while peacebuilding is the stated goal, the peacebuilding trajectories and students' commitment to this end are rarely addressed.

The article first explores the debates that frame textbook analysis in the field of comparative and international education. Then it builds the case for a comparative analysis by contextualising the Colombian and South African case studies. After presenting our findings, we conclude that through similar methods of historical revisionism, the role of one group over many others in dismantling structurally violent regimes is achieved at the expense of other actors. This proves to be counterproductive to the peacebuilding process as well as the development of students' engagement in the peacebuilding process.

\section{PEACEBUILDING, STRUCTURAL VIOLENCE, AND TEXTBOOK ANALYSIS}

While we analyse the manner in which textbooks discuss violence, we also analyse the opportunities textbooks create to promote peacebuilding. It is widely accepted that textbooks are grounded by ideologies - ideologies that, at times, may be in competition with each other (Apple 1990; Altbach 1991; Altbach \& Gopinathan 1985; Altbach \& Kelly 1988; de Castell 1990; Foulds 2013a; van Brummelen 1990). Controversies over official knowledge, presented by the state in textbooks, signify profound political, economic, and cultural histories (Apple 2014). These controversies centre on what is included as much as what is excluded, underscoring that textbooks represent specific constructions of reality situated within a particular socio cultural-historic time frame (Apple 2014). Rather the process of knowledge development, and thus cultural incorporation, is dynamic and reflects both the stability and volatility of the dominant culture (Apple 2014). It is in these contradictions that opportunities emerge for students to develop and adapt peacebuilding skills.

Recent work in the field of comparative and international education has approached textbooks as cultural objects that reflect broader social issues. Within this framework, textbooks are not necessarily perceived as pedagogical tools, but as artefacts compounded by sets of representations. One strand of research focuses on the expansion and translation of global discourses into national textbooks looking at representations of human rights, multicultural education and student-centred approaches to pedagogy (Bromley, Meyer \& Ramírez 2011; Buckner \& Russell 2013; Terra \& Bromley 2012). Another line of work problematises exclusionary depictions of the nation-state, and the manner in which textbooks portray values associated with national identity and national citizenship (Asanova 2007; vom Hau 2009; Williams 2014). Closely related to our focus 
of concern, Alayan (2016), Bellino (2014), Ngo (2014), and Yogev (2014) examine the politics of misrecognition in the content that is included and removed from textbooks in post-conflict scenarios. These three analytical perspectives prioritise textbooks as representational devices. We see a problematic gap between scholarship devoted to the representational analysis of textbooks and its pedagogical dimension. By analysing how textbooks represent violence in contexts affected by high levels of violence, we make a significant contribution towards thinking about textbooks as material artefacts that enable a conversation about violence in the classroom. Another contribution is that our work links the politics of recognition to pedagogical practice, and therefore to social change. Even though we are aware that teachers and students constantly re-contextualise and adapt textbook content in the classroom (Porat 2004; vom Hau 2009), this paper approaches textbooks as pedagogical tools with the potential to promote peacebuilding.

In this article we analyse the extent to and manner in which representations of violence in social studies textbooks support (or do not support) peacebuilding. By analysing the potential of social studies textbooks to promote peacebuilding, this paper furthers the relationship between education and peacebuilding (Novelli, Lopes Cardozo $\&$ Smith 2014). Here we define peacebuilding as a set of localised and transformative actions that multiple actors undertake to contain and overcome conflict. In this regard, peacebuilding entails parallel processes of personal and relational change alongside structural transformation (Lederach 1995). Within peacebuilding agendas, education is perceived as an opportunity for social transformation. We maintain that textbooks can contribute to peacebuilding through an explicit focus on changing individual attitudes and raising students' critical awareness of the multiple dimensions of violence.

Peacebuilding in the classroom implies that students learn to humanise the other (Gill \& Niens 2014). As part of the humanisation process, students develop criticalthinking skills that allow them to reflect on their own positionality and understand social fragmentation as the result of human decisions. Under this umbrella, violence is perceived as preventable social phenomena. The premise of our work is that textbooks must address the interconnectedness between the individual and the structural components of violence, and thus recognise a series of relationships between individual actions and broader structural arrangements. School research tends to focus on the most visible manifestations of violence - verbal and physical threats, physical punishment, robbery, sexual assaults, weapon use, and cyber violence, among others. Here, we prioritise the exchanges between individual actions and the socio-economic apparatus that perpetuate violence. In contrast to the high visibility of physical interpersonal violence, structural violence is largely perceived as the natural order of things. To denaturalise this order, we define structural violence as the social arrangements that create disadvantage for particular groups of individuals. Farmer $(2006,307)$ defines structural violence, as that form of 'violence exerted systematically - that is, indirectly - by everyone who belongs to a certain social order'. This form of violence is embedded in larger social, political, and economic matrixes. It promotes the unequal distribution of social suffering and 
misery at the same time that it constrains the range of individual choices (ScheperHughes \& Bourgois 2006). To focus on individual responsibilities in the reproduction of structural violence allows us to revisit textbooks' potential to promote social change.

\section{BUILDING A COMPARATIVE CASE}

In this section, we introduce the particular backgrounds of the country case studies to better contextualise the textbook analysis. The two case studies provide a high degree of contrast regarding the relationship between education and inequality, in terms of geographical diversity, the nature and temporality of the conflict contexts, and the drivers and root causes that underpin those conflicts. The cases also offer a rich demonstration of the capacity and commitment of different states to effect durable peace and social cohesion through education.

Still reeling from the end of apartheid in all spheres of life - political, economic and social - South Africa provides a rich resource for reflecting on the historical challenges and possibilities for the education system in promoting sustainable peacebuilding. Violence, both structural and personal, remains apartheid's legacy in South Africa, even 22 years after its dismantling. Apartheid, as a system of rule, maintained its order partly through physical violence carried out by police in the form of beatings, torture and murder. In an attempt to address the resulting physical and emotional scars, the South African government established the Truth and Reconciliation Commission (TRC) in 1995. To build national unity by bringing together victims and perpetrators, the TRC focused on promoting 'national unity and reconciliation in a spirit of understanding which transcends the conflicts and divisions of the past' (Promotion of National Unity and Reconciliation Act, No. 34 of 1995).

Ongoing violence, however, rooted in the apartheid legacy undermines and prevents efforts at reconciliation, healing, and building sustainable peace (Harris 2006). In 2012, South Africa had one of the highest murder rates globally, with historically high homicide rates at 31 murders per 100,000 people (UNODC 2013). A study conducted by the Centre for the Study of Violence and Reconciliation found that the nation-building rhetoric of the Nelson Mandela and TRC era fed 'into a (new) xenophobic South African identity [that] is not completely removed from the (old) racism of the apartheid order, as seen in the targets of this hostility, namely black Africans' (Harris 2006, 29). By not explicitly addressing racist violence in its agenda, the TRC inadequately addressed these divisions, thereby failing to address the root causes of the multiple forms of violence. This has also led to increased levels of xenophobic hostility, primarily expressed towards migrant workers and refugees (Harris 2006; Dodson 2010; Neocosmos 2010; Hickel 2014).

Colombia still faces the consequences of a 60 -year-long conflict between the state, left-wing guerrilla groups, and right-wing paramilitary forces. Rooted in political and economic exclusion, the armed conflict has caused horrific violence, particularly in rural areas of the country where 1,981 massacres have been registered in the last 30 
years (Centro de Memoria Histórica 2016). The government reports 8,131,269 victims, including internally and externally displaced people (Unidad de víctimas 2016). In a country of approximately 40 million inhabitants that means that roughly one in five inhabitants have been direct victims of the violence. The causes of the armed conflict in Colombia include the unequal distribution of land, a fragile state with poor capacity to rule, bipartisan violence during the 1950s, and the establishment of the Frente Nacional (National Front) (1958-1974), an arrangement in which the two elite political parties joined forces and agreed to govern without opposition for a period of four presidential terms, which exacerbated the exclusion of marginalised sectors (Moncayo \& Pizarro 2015). The use of land for drug-cropping purposes brought new economic disputes over territorial control, sparking more violence across the country, and in turn, another cycle of killings and displacements (Moncayo \& Pizarro 2015). The case of Colombia allows us to understand the dramatic consequences of structural violence, manifested in formal political exclusion and economic maldistribution.

Most current South African conflicts are firmly rooted in a history of colonialism and apartheid that not only fractured social identities along the lines of race, but solidified them in unequal relations that continue to separate the population across unequally resourced spatial areas (Sayed et al. 2016). In 1994, the new government made a commitment to address issues of equity and social cohesion. However, more than two decades after the end of apartheid the legacies of past policies remain, and much of the physical landscape of apartheid has undergone very little change. The education system mirrors the inequalities and legacies of apartheid. For example, in 2012 South Africa invested 6.8 per cent of the gross national product (GNP) and 20.6 per cent of total government expenditure in education (which is much higher than the world average), yet children from more privileged backgrounds continue to have a higher chance of matriculating by the age of 19 or 20 than children from poorer backgrounds. Statistics show that 88 per cent of privileged students reach matriculation compared to only 17 per cent of those from poorer backgrounds (SAHRC \& UNICEF 2014). After 1994, the ANC government attempted to redress many of these inequalities and to bring about effective and meaningful structural changes. In so doing, it reorganised the system according to key debates related to decentralisation, values, languages of instruction, learner safety, minimum norms and standards for public school infrastructure, and affirming the rights of all learners.

Between 2012 and 2016 the Colombian government engaged in peace talks with the FARC. As a result of agreements regarding FARC's total disarmament, along with forms of restitution to the victims and justice for those found to have committed warrelated crimes, a peace accord has recently been signed (Gobierno nacional \& FARCEP 2016). Even though the peace accord was rejected by a slight majority $(50.21 \%$ versus $49.78 \%$ ), the peace process is not dead as the forces that supported it struggle to keep the process moving forward. In the meantime, Colombia's education budget has increased by 5.75 per cent, reflecting the government's commitment to peacebuilding 
through education. In Colombia, schools have the autonomy to design their own curricula. However, to provide more guidance, the National Ministry of Education (MEN) established competency-based standards for citizenship, language, Mathematics, Natural Sciences, and Social Sciences in the early 2000s. MEN does not consider the guidelines compulsory; nevertheless, these guidelines frame the standardised national exams. In contrast to neighbouring countries Ecuador and Venezuela, textbooks in Colombia are produced by private publishing houses. The General Law of Education (1994) did not regulate textbook content. As a result, textbook authors have wiggle room to make decisions regarding topic selection.

\section{METHODS AND DATA ANALYSIS}

While peacebuilding occurs in many ways, schooling arguably plays a significant role. This is particularly true for those countries emerging from a history of conflict and division, as in the cases of Colombia and South Africa. Since textbooks are the physical manifestations of the written curriculum, the purpose of this study is to analyse and compare how Colombian and South African textbooks (re)present violence as part of the post-conflict transition. We specifically examine how a commonly used Social Science textbook in each country projects and constructs conflicts and create opportunities for peacebuilding within the classroom. We specifically ask: How do textbooks explain past and present injustices? How is difference recognised, if at all? What opportunities exist to promote social change through critical analysis of the many forms of violence experienced in protracted conflicts?

To address these questions, we have selected one textbook from each country targeted at Grade 9 learners. In particular, we focus on Social Science textbooks in Colombia and South Africa - textbooks specifically considering the subject of History, as they represent in both countries important 'carrier subjects' for an understanding of the historical legacy of violence, for projecting the new inclusive society that must come into being, and for addressing the causes and consequences of inequality in society. As such, they express the curriculum values of critical and active citizenship and unity in diversity as the touchstone principles for dealing with the historical legacies of conflict (Sayed et al. 2016).

We use critical discourse analysis (CDA) (Fairclough 2003) to understand 'who speaks, when and with what authority' (Ball 1990, 17) in the selected textbooks. CDA is relevant here, as it views language 'as a cultural tool [that] mediates relationships of power and privilege in social interactions, institutions, and bodies of knowledge' (Rogers et al. 2005, 367). In CDA, language is seen as a social practice of power: discourse both reflects social, economic, cultural and political formations while it constructs the social world (Rogers et al. 2005, 369). In our approach to CDA, we analyse both the overall structure and main messages of the textbook, as well as specific topics and words and their meanings in relation to issues of violence (Wodak \& Meyer 2001). We also focus 
on the textbooks' instructional component. To this end we have developed a specific textbook analysis template for qualitative in-depth CDA analysis of the selected topics.

For the South African context, we selected the Platinum Social Sciences Grade 9 Learner's Book, published in South Africa by Maskew Miller Longman. The book is divided into two subjects: Geography and History (Ranby \& Johannesson 2014). The first subject, Geography, covers map skills, development issues, surface forces that shape the earth, and resource use and sustainability (1-104). The second subject, History, covers World War II (106-135) and the Cold War (136-167) before turning to modern South African history. Modern South African history is divided into two segments: Turning points in modern South African history since 1948, and turning points in modern South African history 1960, 1976, and 1990 (168-264).

For the Colombian case, we selected Proyecto Saberes 9 (Project Wisdom), published by Santillana - a global publishing house with an international presence in 22 Spanish- and Portuguese-speaking countries. The Proyecto Saberes Grade 9 is divided into eight units. To analyse the opportunities for peacebuilding the textbook offers, we prioritised lessons devoted to the emergence and development of the Colombian armed conflict. The phrase 'conflicto armado' (armed conflict) is a defining way in which Colombians understand and relate to their national history (Moncayo \& Pizarro 2015). The Colombian armed conflict appears in three units: 'Government and Public Power', 'Colombia during the First Half of the Twentieth Century', and 'Colombia during the Second Half of the Twentieth Century'. Considering most sources agree that the Colombian armed conflict started in 1948, we prioritise the analysis of the content related to contemporary Colombia, but still analyse one section of the sixth unit on the historical period between the 1930s and 1950s known in Colombia as La Violencia (The Violence). The unit on contemporary Colombia includes sections in political and economic history, but more importantly for the purpose of this paper, it addresses the 60 years of armed conflict in Colombia.

\section{FINDINGS: SOUTH AFRICA}

In 2011, South Africa unveiled the revised Curriculum and Assessment Policy Statements (CAPS), which were focused on healing divisions of the past and establishing a society based on democratic values, human rights, and a government based on the will of the people and equal exercise of law in order to build a unified South Africa. CAPS emerged from a history of curriculum policy contestation and revision. In 1994, the government undertook curriculum cleansing to edit out racist language, as well as controversial and outdated content. In 1997, the new national Department of Education (DoE) launched Curriculum 2005 to serve as the foundation for post-apartheid education. In 2000, Curriculum 2005 (up to Grade 9) was reviewed and revised resulting in the Revised National Curriculum Statement (Chisholm 2005). Between 2006 and 2011, CAPS was developed as the more accessible version of the NCS. In its current state, the History 
curriculum emphasises the development of key critical skills and a strong focus on engaging with issues particular to the South African experience but located within a global human rights paradigm.

As discussed previously, we privileged the Platinum Social Sciences Grade 9 Learner's Book for our analysis (Ranby \& Johannesson 2014). The following findings draw from textbook lessons devoted to conflict during apartheid in South Africa: the formation of the ANC, the Sharpeville massacre, the Langa march, the Rivonia trial, the Soweto uprising, and Nelson Mandela's release and the unbanning of the liberation movement.

\section{Violence, the ANC, and historical revisionism}

In discussing each of the events noted above, the textbook makes significant effort to identify the events that lead to each, with a strong focus on showing the active, nonviolent resistance of black South Africans against apartheid policies and practices. There is a clear commitment to defining protests and demonstrations led by the ANC as non-violent events, in sharp contrast to the violence perpetuated by the Apartheid regime. Regarding when the anti-apartheid movement transitioned from passive to violent resistance, and specifically when the ANC made this transition, the textbook contains a number of inconsistencies, particularly in its contradictions when discussing the activities of the ANC.

The unit covering the Sharpeville massacre provides an example of the dichotomy between the non-violence of the anti-apartheid movement and the violence perpetuated by the Apartheid regime. The book uses this example to introduce and reinforce critical history by encouraging an analytical historical lens through contesting narratives of police as victims. A sample of the anecdotes includes the following (Ranby \& Johannesson 2014, 211):

- High Commissioner: According to factual information now available, the disturbances at Sharpeville on Monday resulted from a planned demonstration of about 20,000 natives in which demonstrators attacked the Police with assorted weapons including firearms. The demonstrators shot first, and the police were forced to fire in self-defence and avoid even more tragic results. The allegation that the demonstrators were unarmed and peaceful is therefore completely untrue.

- Magazine reporter: I heard no warning to the crowd to disperse. When the shooting started it did not stop until there was no living thing in the huge compound in front of the police station. The police have claimed they were in desperate danger because the crowd was stoning them. Yet only three policemen were reported to have been hit by stones - and more than 200 Africans were shot down. 
- Magazine photographer: The cops were in no danger. I can only assume that they came out with the intention of showing the crowd, and in the process black South Africa, a dreadful lesson.

Photographs of protestors fleeing and people tending to the wounded corroborate the anecdotes of violence against the protestors. This section is then followed by a 'skills focus', which explains the difference between an opinion and a fact, and then presents a series of questions that ask students to explore the variations in accounts, asking students to 'explain why the [High Commissioner] exaggerated the size of the crowd'. Students are also asked, 'Who was to blame for the events of Sharpeville?' (Ranby \& Johannesson 2014, 212).

Though the unit on the Sharpeville massacre was not affiliated with a specific antiapartheid organisation, the textbook focuses on the contributions of the ANC almost exclusively. The textbook writes that the ANC was formed in January 1912, with a vision to 'bring all Africans together, to defend their rights and freedoms', and was focused on resistance through petitions, discussions, and resolutions in its early days $(2014,191)$. The book then details the 1949 Programme of Action; Albert Luthuli's role in the ANC; the ANC's Defiance Campaign; Mahatma Gandhi's influence on the ANC; the ANC's Freedom Charter; its alliance with the South African Indian Congress, the South African Coloured People's Organisation, the South African Congress of Trade Unions, and the Congress of Democrats; and it also details the Women's March, including a focus on Helen Joseph and Lillian Ngoyi (198-206). While not all of these historic events are ANC-centric, the overwhelming majority are focused on ANC activities.

As the textbook transitions to turning points since 1960, there is a clear effort to juxtapose the ANC's democratic approach of aligning itself with other marginalised racial and ethnic groups in the country with the actions of other anti-apartheid organisations. For example, the book discusses the Pan Africanist Congress's (PAC) specific strategic vision for partner organisation and members:

This organisation believed that the struggle against apartheid was an African struggle. They did not want to work with organisations which were not African. They especially did not want to work with white organisations such as the Congress of Democrats. The PAC was not racist, but believed that white people had too much to lose to be reliable allies. (Ranby \& Johannesson 2014, 208)

The discussion of the creation of the PAC has a distinct framing: the PAC was 'formed by a group of renegade ANC members' (208, emphasis in the original). In 1958, these 'renegade' members wanted South Africa returned to its indigenous inhabitants, and were unwilling to support equal rights for all races because of a focus on the individual versus the group, both stances that were in sharp contrast to the ANC's non-racial democracy (Horowitz 1991). The textbook, however, does not provide students with any information or suggestion that dissent existed within the ANC. 
When anti-apartheid organisations engaged in violent acts, the textbook makes it clear that the goals were different and that the focus was on non-human targets. The book argues that the Sharpeville massacre and the Langa march were key turning points in the history of apartheid, because they led to a law that banned both the ANC and PAC, forcing the anti-apartheid struggle to shift from passive to violent resistance. A section on the Umkhonto we Sizwe (MK), an armed movement in the ANC led by Nelson Mandela, explains how MK attacked over 200 non-human targets throughout South Africa between 1961 and 1963. While the targets included government buildings, the book notes, 'Care was taken not to cause loss of life, but in the Eastern Cape some people who were cooperating with the Bantustan leaders in the Transkei, were killed' (Ranby \& Johannesson 2014, 215). The historical revision of these violent activities during apartheid, however, is in stark contrast to why MK existed. In reality, while MK did attack non-human targets, as the book indicates, other bombing sites included churches, bars, courts, and banks (Tutu 2003). As Mandela famously explained, in a statement written while in prison:

It was only then, when all other forms of resistance were no longer open to us, that we turned to armed struggle ....Let [Botha] renounce violence. Let him say that he will dismantle apartheid. Let him unban the people's organisation, the African National Congress. Let him free all who have been imprisoned, banished or exiled for their opposition to apartheid. (Mandela 1985)

The misrepresentation of MK is further compounded by the ways in which other antiapartheid groups violently resisted the regime, with the effect of rationalising and limiting the violence of one organisation and portraying the ANC more positively than other groups. For example, the PAC's armed wing, Poqo, is introduced in opposition to MK: 'Unlike MK, Poqo made no effort to avoid loss of life' (Ranby \& Johannesson 2014, 216). The textbook further details the 'brutal nature' of Poqo and its activities, all of which ultimately resulted in the death of 'innocent white people, including women and children' (ibid.).

The book's contradictions in framing violent resistance among anti-apartheid groups are further highlighted in a unit on the Rivonia trial. In 1962, Mandela was arrested for travelling outside SA without a passport. Eight months later, police raided MK's headquarters, leading to the arrest, detention, and torture of MK leaders. Under the General Law Amendment Act, police could hold people in jail if they were suspected of political crimes (Ranby \& Johannesson 2014, 217). During the trial of these leaders, known as the Rivonia trial, the state anticipated that Mandela would take the stand. As the book explains, in a section that reads as narrative rather than historical telling, 'The state prosecutor, Dr. Percy Yutar, had prepared to cross-examine Mandela and break him down. He got a shock when the ANC lawyers announced that Mandela would not give evidence but instead would make a statement from the dock' (218). Mandela's statement, included in the textbook, includes an affirmation of the violent resistance of the apartheid state: 
During my lifetime I have dedicated myself to this struggle of the African people. I have fought against white domination, and I have fought against black domination. I have cherished the ideal of a democratic and free society in which all persons live together in harmony and with equal opportunities. It is an ideal, which I hope to live for and to achieve. But if needs be, it is an ideal for which I am prepared to die. (Ranby \& Johannesson 2014, 218)

While Mandela's statements, some of which are included in the textbook, depict his and the ANC's commitment to violent resistance as a necessity of last resort for the struggle, the textbook consistently creates a revisionist narrative of both the ANC and Mandela, and therefore provides inadequate space for students critically to engage historical events.

\section{FINDINGS: COLOMBIA}

In line with the Delors Report, students in Colombia are expected to learn to know, learn to do, learn to be, and learn to live together (UNESCO 1996). To do so the Ministry of Education fosters a competence-based approach. Social Sciences, a subject that brings together history, geography, economy, and democracy, cover three competences: 'I approach knowledge as a social scientist', 'I understand social sciences knowledge', and 'I develop personal and social commitment' (MEN 2004a, 11). These are complemented with citizenship competences (MEN 2004b). The Social Sciences competences define education as a means to cultivate a strong sense of belonging that aims to bring communities together and grow responsibility towards the public sector and the nation. Through attitudes that include curiosity, flexibility, persistence, open-mindedness, tolerance, reflection, teamwork, and ethical behaviour, the ideal citizen is expected to cultivate tolerance towards diversity, strong critical-thinking and communicative skills, and commitment towards the environment (MEN 2004a).

This competence-based approach aims to help students find their learning experience meaningful. On the other hand, through a human-rights based approach, the purpose of citizenship competences is to 'provide basic tools for each person to respect, defend and promote fundamental rights relating them to everyday life situations' (MEN 2004b, 6). This set of competences emphasises the development of skills and knowledge that in the near future will allow students to learn to live together, promote democratic participation, and value difference in their daily life. In the next section we analyse the extent to which Proyecto Saberes 9 portrays violence, armed conflict, and peacebuilding through this framework.

\section{Violence: The multitasking concept}

'Violence' is used in the textbook to describe quite different phenomena. The generous use of the term 'violence' has the potential to distract readers from understanding the multiple forms of social suffering violence hides. Without providing a definition - nor 
the opportunity to reflect and create one-readers jump from political violence to genderbased violence to domestic violence without being asked what these three phenomena have in common. Aligned with national historiographical debates, the textbook also treats La Violencia (The Violence) as a historical period, as a context descriptor, and an independent force that grows and spreads across the country. Despite the claims to relevancy that appear in the Social Science and citizenship competences, the units neglect other forms of violence closer to students' everyday life experiences, such as bullying.

Proyecto Saberes 9 presents a weak representation of the structural components of violence. For example, the section entitled 'Violencia y conflicto armado' (Violence and armed conflict) aims to record the factors behind the country's high levels of violence. By listing and connecting 'poverty, exclusion, and abandonment' (Marabolí et al. 2016, 275 ) to the recruitment of children and their participation in illegal armed groups, the textbook suggests a connection between social exclusion and violence. But the weakness of this suggestion might reify the image of society's most marginalised as society's most violent members, especially as the next section alludes to scientific knowledge that 'shows' a correlation between high levels of domestic violence, low income, low educational attainment, and poor health. 'Violence' ends up being trivialised by its extensive use, and by the lack of opportunities to conceptualise its causes, consequences, and manifestations.

\section{The representation of the armed conflict as a distant (and presidential) affair}

In describing the chain of events that frame the armed conflict, the narrative allocates responsibility to the hands of a few: the state and the non-state armed actors. The government is portrayed as an omnipotent force that causes and solves the armed conflict. Here the textbook conceals the identity of other armed actors, and suppresses civil society as a key actor in the peacebuilding and reconciliation process. This emphasis on the role of the state might prevent teachers and students from connecting their own life stories with the country's present and future.

Similar to Colombian high school textbooks published between 1977 and 1987, Proyecto Saberes 9 provides an elaborate account of the development of the political history of the country, while paying little attention to everyday life experiences (Meyer, Bromley \& Ramírez 2010). In this context, and in line with 'the big man theory of history' (Zinn 1995), Colombia's history is narrated through the mandates of Colombia's presidents - all white males from relatively privileged backgrounds; their deeds effect Colombia's transformation. The unit follows a chronological tale of Colombia's most recent presidential periods. Each president has a brief description of the main achievements, and the challenges he faced, yet the economic issues of each term are placed in an extended description of the country's economy, appearing under a 
different subtitle - 'The Colombian Economy'. This visual and content division reduces the prospects of analyses that connect economic exclusion with political violence.

By obscuring the role and experiences of other social actors, the textbook allocates more status to presidents than to any other group. For example, to describe the country in the late ' $30 \mathrm{~s}$, the textbook claims, 'To face this social discomfort, President Olaya Herrera was compelled to establish peace policies such as weapon collection, the militarization of the regions and the persecution and imprisonment of those responsible' (Marabolí et al. 2016, 187). This portrayal not only obscures tensions between different social actors at that historical moment, but also neutralises highly controversial terms, such as pacification, militarisation, persecution, and capture. Then, to explain the origin of leftist guerrillas FARC and Ejército de Liberación Nacional (ELN) (National Liberation Army), the book maintains the presidential gaze:

Guillermo Leon Valencia (1962-1966). This conservative ruler faced problems of public policy, his attempt to eliminate the so-called 'independent republics' - regions of the country where movements of peasant self-defense near the Communist Party existed - caused the radicalization of several residents of these areas, whom in 1964 founded the groups guerrillas of the Revolutionary Armed Forces of Colombia (FARC) and National Liberation Army (ELN). (Marabolí et al. 2016, 251)

In tackling the emergence of social movements and armed groups, Proyecto Saberes 9 reduces the causes of violence to political exclusion, leaving behind the dire poverty of Colombia's most marginalised. For example, the textbook claims La Violencia is the period of Colombian history, between 1930 and 1957, in which the two traditional political parties - Liberals and Conservatives - 'clashed by force of arms in different regions of the country when political agreement could not be achieved' (p. 187). Later, in the section devoted to the analysis of contemporary Colombia, it maintains that violence was the direct consequence of a power struggle between the two main political parties: 'Bitter struggle for power between the two political parties' (250). Furthermore, it declares:

Being politically excluded [by the National Front], these organizations laid the political basis on which guerrilla movements appeared, including: the Peasant Student Workers Movement (MOEC) in 1960; the National Liberation Army (ELN) in 1964; The Revolutionary Armed Forces of Colombia (FARC) in 1964; the People's Liberation Army (PLA), in 1965; and the April 19 Movement (M-19) in 1974. (Marabolí et al. 2016, 253)

The oversimplification of the guerrillas' motivations not only decontextualises the guerrillas' initial struggle, but also reduces the causes of the armed conflict to a single narrative.

Except for brief allusions to campesinos (farmers) that joined the guerrillas, the textbook implies that those directly involved in the armed conflict were class-less, race-less, and gender-less. The identity of armed actors is reduced to their political affiliation. For example, 'During La Violencia different armed groups clashed in 
several areas of the country. Most of them were linked to a political party and used the pretext of political struggle to commit brutal acts' (188). By de-humanising those who actively participate in the Colombian armed conflict, the textbook reduces the chances to promote empathy and understanding across political factions. Additionally, despite the extended presence of discussions about violence throughout the unit, the sufferers of violence have insignificant presence. Seven pages before the textbook ends, under the sub-heading, 'How does the Colombian government provide care and restore the armed conflict victims' rights?' (282), the textbook invites students to do research on the different plans the state has implemented to protect internally displaced people, and to identify those victims who have received greater benefits. This segment does not include victims' testimonies or the opportunity to reflect on the multiple affiliations that students and their families maintain with armed conflict actors (Rodríguez-Gómez 2016).

Discussions about peace portray peacebuilding as a governmental effort. While emphasising presidents as peace (or war) makers, the textbook narrative neglects the role of civil society in the promotion of peace. Proyecto Saberes 9 only creates one opportunity for students to reflect on their own responsibility towards peacebuilding. After describing the current peace dialogues between the government and the FARC, the textbook presents a short activity that invites students to analyse a quote from Juan Manual Santos, Colombia's current president, and to answer, 'What actions could you do from your school to contribute to peace in the country?' (Marabolí et al. 2016, 271).

\section{DISCUSSION}

The examples used here to analyse how textbooks represent violence demonstrate distinctive approaches to displaying national conflict, and thus present unique narratives related to the construction of peace in post-conflict settings. Returning to our questions of how the selected textbooks articulate national conflict as part of a national peacebuilding process, we find that while there is an extended presence of topics related to conflict and peacebuilding, the textbooks inadequately explore both the structural dimension of violence, and the interconnectedness between individual actions and broader societal arrangements.

In the South African context, while the textbook highlights the success of nonviolent ANC-led protests and demonstrations in ending apartheid, the historical narrative around the transition of the anti-apartheid movement, specifically the ANC, from passive to violent resistance is filled with contradictions and inconsistencies. The textbook furthers these contradictions through the misrepresentation of the armed wing of the ANC, MK. The textbook minimises the violent actions of MK in a clear effort to maintain a hierarchy of anti-apartheid groups. In providing an incomplete historical narrative of violent activities carried out by the ANC, the textbook fails to discuss the complete spectrum of their activities while also equating violence with ineffectiveness. 
These depictions are all in obvious contrast to the stated objectives of the ANC and its leaders.

By inadequately addressing the realities of the physical violence of the antiapartheid movement as a means of dismantling the structural violence of apartheid, the textbook provides an incomplete historical narrative and therefore does not fulfil its commitment to support students' critical-thinking skills development. These issues parallel the critiques of the TRC and its failure to address the root causes of the multiple forms of apartheid violence. The continuation of a narrative that suggests violence is a preventable phenomenon and/or limited to peripheral groups - certainly not the current ruling political party - presents a narrative counter to the notion of national unity, and thus peacebuilding, by failing to build a critical awareness of the many dimensions of violence.

Also noticeably absent in textbook depictions, and thus the analysis provided here, are representations and analyses of the cyclical and everyday forms of violence experienced by black and coloured South Africans. This includes, but is not limited to, racial segregation via a concentration of socio-economic resources in white suburbs and the forced migration of black South Africans to under-resourced urban peripheries, restricted movement, passbook laws, unlawful imprisonment, physical violence without consequence, limited economic opportunities, and inadequately-funded schools and hospitals (Hindson, Byerley \& Morris 1994; Simpson 2004). Similarly, the textbook normalises the existence of perpetrators of violence under the Apartheid regime, missing an opportunity to understand the relationship between an individual and particular situations or environments that transforms one into a violent perpetrator (Freedman et al 2008; Foulds 2013b; Kraft 2015). An understanding of apartheid, per the textbook's included topics, is to understand major violent events. This absence, however, mimics the TRC's focus on reconciliation and the treatment of violence in a linear, specific, and event-based way (Harris 2006; Simpson 2004).

If the South African case exemplifies the banalisation of violence through the misrepresentation of violent and non-violent actions, the Colombian case presents an excessive use of the term, which dehumanises armed-conflict actors and war victims, and disconnects violence from social suffering. Astonishingly, Colombia's presidents end up being the human faces of the armed conflict. Amidst a peace and reconciliation process, Proyecto Saberes 9 offers few pedagogical resources to recognise armedconflict actors, civil society, and victims as members of the same national community. Similar to the South African case, the textbook both bolsters the role of the state in resolving the armed conflict while reducing the importance of civil society as a key contributor to peacebuilding and reconciliation. Civil society's absence has the potential to limit students' opportunities to recognise themselves and their families as active players in such processes. Furthermore, the fact that the textbook portrays the armed conflict as a distant event, isolated from broader socio-economic factors, forecloses the prospects for understanding how political violence is embedded in broader socioeconomic arrangements. 
Despite the Social Science and citizenship emphasis on the development of criticalthinking skills and relevant competences, Proyecto Saberes 9 shows how a positivist interpretation of history obscures the potential of Social Science content for generating an understanding of and respect for multiple narratives, and therefore developing peacebuilding skills.

\section{CONCLUSION}

Articulating violent protracted conflicts in the curricula of states only recently emerging from these events provides both opportunity and challenge. Regardless of position on the conflict/post-conflict continuum, as evidenced in the analysis of Colombia and South Africa, a national curriculum that seeks to confront the link between conflict and social cohesion as a peacebuilding process unveils the contradictions and continuities of maintaining the dominant culture. Governments look to revised national curricula to support national peacebuilding efforts through learning materials that present historical narratives exploring the causes and effects of the conflict while also reinforcing the position of the current ruling party. Because of these multiple responsibilities, and despite the flaws in conceptualisations of violence analysed in this study, textbooks should not be viewed in isolation but as part of a larger pedagogy of peacebuilding and national reconciliation. Their content is discussed in the classroom not only on their own merits or their relationships with other curricula, but is interpreted in light of national agendas, sensibilities, and trajectories. As such, they represent a valuable opportunity not only to elicit the ideologies around violence and armed conflict but, more importantly, to promote another environment in which these processes of peacebuilding can unfold.

The findings in this paper demonstrate that these processes, however, cannot unfold when the narratives provided in Social Sciences textbooks focusing on the subject of History are incomplete and inadequately address the causes and effects of structural and physical violence. As such the textbooks may unintentionally reinforce the processes and systems that maintain inequality and which may result in violence. At the same time, the History curriculum in Social Sciences textbooks can play a key role in helping students to learn about the past and the forces that shaped it in order heal the divisions created by that same past.

\section{ACKNOWLEDGMENT}

We would like to thank the ESRC-DFID for a research grant for the project Engaging Teachers in Peacebuilding in Postconflict Contexts: Rwanda and South Africa (PI: Yusuf Sayed). However, the views expressed in this paper reflect that of the authors and not the funders. 


\section{REFERENCES}

Alayan, S. 2016. The Holocaust in Palestinian textbooks: Differences and similarities in Israel and Palestine. Comparative Education Review 60(1): 80-104.

Altbach, P. and S. Gopinathan. 1985. Textbooks in the Third World: Challenge and response. In Publishing in the Third World: Knowledge and development. Edited by P. Altbach, A. Arboleda and S. Gopinathan, 13-24. Portsmouth: Heinemann.

Altbach, P. and G. Kelly. 1988. Textbooks and the Third World: An overview. In Textbooks in the Third World: Policy, content and context. Edited by P. Altbach and G. Kelly, 3-17. New York: Garland Publishing.

Altbach, P. 1991. Textbooks: The international dimension. In The politics of the textbook. Edited by M. Apple and L. Christian-Smith, 242-258. New York: Routledge.

Apple, M. 1990. The text and cultural politics. The Journal of Educational Knowledge 24(3A): 18-33.

Apple, M. 2014. Official knowledge: Democratic education in a conservative age. New York: Routledge.

Asanova, J. 2007. Teaching the canon? Nation-building and post-Soviet Kazakhstan's literature textbooks. Compare: A Journal of Comparative and International Education 37(3): 325-343.

Ball, S. 1990. Education reform: A critical and post-structural approach. Philadelphia: Open University Press.

Bellino, M.J. 2014. Whose past, whose present? Historical memory among the 'postwar' generation in Guatemala. In (Re)constructing memory: School textbooks and the imagination of the nation. Edited by J. Williams, 131-152. Rotterdam: Sense Publishers.

Bromley, P., J. Meyer and F. Ramírez. 2011. Student-centeredness in social science textbooks, 1970-2008: A cross-national study. Social Forces 90(2): 1-24.

Brown, G. 2011. The influence of education on violent conflict and peace: Inequality, opportunity and the management of diversity. Prospects 41(2): 191-204.

Buckner, E. and S.G. Russell. 2013. Portraying the global: Cross-national trends in textbooks' portrayal of globalization and global citizenship. International Studies Quarterly 57(4): 738-750.

Burton, P. and L. Leoschut. 2013. School violence in South Africa. Results of the 2012 National School Violence Study. Centre for Justice and Crime Prevention. Retrieved from: http://www.cjcp.org. za/uploads/2/7/8/4/27845461/monograph12-school-violence-in-south_africa.pdf (accessed 19 July 2016).

Centro de Memoria Histórica. 2016. Masacres 1980-2012. Retrieved from: http://www. centrodememoriahistorica.gov.co/micrositios/informeGeneral/basesDatos.html (accessed 27 July 2016).

Chaux, E. 2009. Citizenship competencies in the midst of a violent political conflict: The Colombian educational response. Harvard Educational Review 79(1): 84-93.

de Castell, S. 1990. Playing by the book: The problem of textbook knowledge. The Journal of Educational Thought 24(3A): 110-113.

Chisholm, L. 2005. The making of South African's national curriculum statements. Journal of Curriculum Studies 37(2): 193-208.

Dodson, B. 2010. Locating xenophobia: Debate, discourse, and everyday experience in Cape Town, South Africa. Africa Today 56(3): 2-22. 
Engelbrecht, A. 2008. The impact of role reversal in representational practices in history textbooks after apartheid. South African Journal of Education 28(4): 519-541.

Fairclough, N. 2003. Analysing discourse. Textual analysis for social research. London: Routledge.

Falgiano, L. and K. LeMaire. 1992. The killings in South Africa: The role of the security forces and the response of the state. Human Rights Quarterly 14(4): 626-628.

Farmer, P. 2004. An anthropology of structural violence. Current Anthropology 45(3): 305-325.

Farmer. P. 2006. On suffering and structural violence: A view from below. In Violence in war and peace. An anthology. Edited by N. Scheper-Hughes and P. Bourgois, 281-290. Oxford: Blackwell.

Foulds, K. 2013a. The continua of identities in postcolonial curricula: Kenyan students' perceptions of gender in school textbooks. International Journal of Educational Development 33(2): 165-174.

Foulds, K. 2013b. Textbooks in post-conflict states: Tensions and opportunities. Working group on peace, conflict, and education, Teachers College, Columbia University. 27 May. Retrieved from: http://blogs.cuit.columbia.edu/peace/2013/05/27/textbooks-in-post-conflict-states-tensionsand-opportunities/ (accessed 19 July 2016).

Freedman, S., H.M. Weinstein, K. Murphy and T. Longman. 2008. Teaching history after identitybased conflicts: The Rwanda experience. Comparative Education Review 52(4): 663-690.

Gill, S. and U. Niens. 2014. Education as humanisation: A theoretical review on the role of dialogic pedagogy in peacebuilding education. Compare: A Journal of Comparative and International Education 44(1): 10-31.

Glynos, J., D. Howarth, A. Norval and E. Speed. 2009. Discourse analysis: Varieties and methods. ESRC National Centre for Research Methods, review paper. Southampton: ESRC National Centre for Research Methods.

Gobierno Nacional \& FARC-EP. 2016. Acuerdo final. Retrieved from: https://www. mesadeconversaciones.com.co/sites/default/files/AcuerdoGeneralTerminacionConflicto.pdf (accessed 5 August 2016).

Government of South Africa. 1995. Promotion of National Unity and Reconciliation, Act, No 34.

Harris, B. 2006. Between a rock and a hard place: Violence, transition, and democratization. A consolidated review of the Violence and Transition Project. Johannesburg: Centre for the Study of Violence and Reconciliation. Retrieved from: http://www.csvr.org.za/wits/papers/papvtp15. htm (accessed 14 August 2016).

Hickel, J. 2014 'Xenophobia' in South Africa: Order, chaos, and the moral economy of witchcraft. Cultural Anthropology 29(1): 103-127.

Hindson, D., M. Byerley and M. Morris. 1994. From violence to reconstruction: The making, disintegration and remaking of an apartheid city. Antipode 26(4): 323-350.

Horowitz, D. 1991. A democratic South Africa?: Constitutional engineering in a divided society. Berkeley: University of California Press.

Kraft, R. 2015. The good intentions of violent perpetrators: A qualitative analysis of testimony from South Africa's Truth and Reconciliation Commission. Peace and Conflict: Journal of Peace Psychology 21(3): 359-377.

Lederach, J.P. 1995. Preparing for peace: Conflict transformation across cultures. Syracuse: Syracuse University Press. 
Low-Beer, A. 2001. Politics, school textbooks and cultural identity: The struggle in Bosnia and Herzegovina. Paradigm 2(3): 1-6.

Mandela, N. 1985. I am not prepared to sell the birthright of the people to be free. Speech presented at Jabulani Stadium, Soweto, South Africa.

Marabolí, V., C.A. Buitrago, J. Pérez and M. Riveros. 2016. Proyecto Saber es ser hacer. Santillana: Colombia.

Meyer, J.W., P. Bromley and F. Ramírez. 2010. Human rights in social science textbooks: Crossnational analyses, 1970-2008. Sociology of Education 83(2): 111-134.

Medel-Añonuevo, C. and G. Mitchell, eds. 2003. Introduction. Citizenship, democracy and lifelong learning. Retrieved from: http://unesdoc.unesco.org/images/0012/001294/129497e.pdf (accessed 3 August 2016).

Ministerio de Educación Nacional. 2004a. Formar en ciencias jel desafio! Lo que necesitamos saber y saber hacer. Bogotá: Ministerio de Educación Nacional.

Ministerio de Educación Nacional. 2004b. Estándares Básicos de Competencias Ciudadanas. Formar para la ciudadanía. . . isi es posible! Lo que necesitamos saber y saber hacer. Bogotá: Ministerio de Educación Nacional.

Moncayo, V. and E. Pizarro. 2015. Contribución al entendimiento del conflicto armado en Colombia: Comisión histórica del conflicto y sus víctimas. Retrieved from: http://static.elespectador.com/ar chivos/2015/02/1952328280f79f83ccb8b9929c8d8fa5.pdf (accessed 4 August 2016).

Neocosmos, M. 2010. From 'foreign natives' to 'native foreigners': Explaining xenophobia in postapartheid South Africa: Citizenship and nationalism, identity and politics. Dakar: CODESRIA.

Ngo, F. 2014. Revision for rights? Nation-building through post-war Cambodian social studies textbooks, 1979-2009. In (Re)constructing memory: School textbooks and the imagination of the nation. Edited by J. Williams, 153-170. Rotterdam: Sense Publishers.

Novelli, M., M. Lopes Cardozo and A. Smith. 2014. A theoretical framework for analysing the contribution of education to sustainable peacebuilding: $4 R s$ in conflict-affected contexts. Retrieved from: http://learningforpeace.unicef.org/wp-content/uploads/2015/05/TheoreticalFramework-Jan15.pdf (accessed 17 July 2016).

Plan International. 2012. Learn without Fear. Third progress report. Retrieved from: https://planinternational.org/publications/learn-without-fear-third-progress-report (accessed 17 July 2016).

Plan Internacional. 2014. El camino del amor. Una vía para desnaturalizar la violencia. Printed version.

Porat, D. 2004. It's not written here, but this is what happened: Students' cultural comprehension of textbook narratives on the Israeli-Arab conflict. American Educational Research Journal 41(4): 963-996.

Ranby, P. and B. Johannesson. 2014. Platinum Social Sciences Grade 9 Learner's Book. Cape Town: Maskew Miller Longman.

Rodríguez-Gómez, D. Forthcoming. When war enters the classroom: A case study on the experiences of youth on the Ecuador-Colombia border. In (Re)constructing memory: Education, identity and conflict. Edited by J. Williams and M. Bellino. Rotterdam: Sense Publishers.

Rogers, R., E. Malancharuvil-Berkes, M. Mosley, D. Hui and G. O'Garro. 2005. Critical discourse analysis in education: A review of the literature. Review of Educational Research 75(3): 365-416. 
Sayed, Y, A. Badroodien, Z. McDonald, A. Hanayo, T. Salmon, L. Balie, T.G. De Kock, W. SirkotteKriel, C. Garisch, J. Gaston and K. Foulds. 2016. Education and social cohesion country report: South Africa. Cape Town: Centre for International Teacher Education.

SAHRC and UNICEF. 2014. Poverty traps and social exclusion among children in South Africa. Pretoria: SAHRC.

Scheper-Hughes, N. and P. Bourgois. 2006. Violence in war and peace. An anthology. Oxford: Blackwell.

Simpson, G. 2004. 'A snake gives birth to a snake': Politics and crime in the transition to democracy in South Africa. In Justice gained? Crime and crime control in South Africa's transition. Edited by B. Dixon and E. van der Spuy, 1-28. Cape Town: Juta Academic Publishers.

Terra, L. and P. Bromley. 2012. The globalization of multicultural education in social science textbooks: Cross-national analyses, 1950-2010. Multicultural Perspectives 14(3): 136-143.

Tutu, D. 2003. Truth and Reconciliation Commission of South Africa Report. Cape Town: The Commission.

UNESCO. 1996. 'Learning: The treasure within'. Report to UNESCO of the International Commission on Education for the 21st Century. Paris: UNESCO.

UNICEF. 2006. Violence against children in schools and educational settings. New York: UNICEF.

UNESCO. 2011. The hidden crisis: Armed conflict and education. Paris: UNESCO.

UNICEF. 2012. Tackling violence in schools. New York: UNICEF.

UNICEF. 2012. Learning for peace. Advancing learning. Building peace. New York: UNICEF.

Unidad de Víctimas. 2016. Asi ha avanzado la reparación a las víctimas. Retrieved from: http://www. unidadvictimas.gov.co/es (accessed 12 November 2016).

van Brummelen, H. 1990. The role of textbooks in inducting children into society. The Journal of Educational Thought 24(3A): 135-137.

vom Hau, M. 2009. Unpacking the school: Textbooks, teachers, and the construction of nationhood in Mexico, Argentina, and Peru. Latin American Research Review 44(3): 127-154.

Williams, J. 2014. (Re)constructing memory: School textbooks and the imagination of the nation. Rotterdam: Sense Publishers.

Wodak, R. and M. Meyer, eds. 2001. Methods of critical discourse analysis. London: SAGE.

Yogev, E. 2014. Studying the past in the present tense: The dilemma of history textbooks in conflictridden areas. In (Re)constructing memory: School textbooks and the imagination of the nation. Edited by J. Williams, 171-190. Rotterdam: Sense Publishers.

Zinn, H. 1995. A people's history of the United States. New York: HarperCollins. 